\title{
Influence of Organic and Inorganic Sources of Nitrogen on Growth and Yield of Radish (Raphanus sativus L.)
}

\author{
B. Naveen $\operatorname{Yadav}^{1 *}$, P. Syam Sundar Reddy ${ }^{1}$, Syed Sadarunnisa ${ }^{1}$, \\ G. Srinivasarao ${ }^{2}$, Y. Deepthi Kiran ${ }^{3}$ and Lalitha Kadiri ${ }^{3}$
}

${ }^{1}$ Department of Vegetable Science, ${ }^{2}$ Department of Soil Science, ${ }^{3}$ Department of Agronomy, College of Horticulture, Dr. Y S R Horticultural University, Anantharajupeta, Railway Kodur, Dr. Y.S.R Kadapa-516105, India

*Corresponding author

\section{A B S T R A C T}

Keywords

Radish, RDN, FYM, Neem cake, Vermi compost, Growth, Yield

Article Info

Accepted:

26 July 2018

Available Online:

10 August 2018
A field experiment was conducted at Vegetables block, College of Horticulture, Anantharajupeta, Andhra Pradesh to study the influence of organic and inorganic sources of nitrogen on growth and yield of radish (Raphanus sativus L.) during Rabi, 2018. The experiment consists of 14 treatments including recommended dose of inorganic fertilizers, FYM, vermicompost, neem cake in different combinations and absolute control. The experiment was laid out in a Randomized Block Design with three replications. The growth parameters were recorded at 30DAS, 45DAS and at harvest. Plant height, leaf length, leaf area, fresh and dry weight of shoot, root length, root diameter, fresh weight and dry weight of root, total biomass per plant, root shoot ratio and root yield were significantly increased by the application of organic and inorganic sources of nitrogen and recorded maximum with treatment $\mathrm{T}_{7}$ i.e., $75 \% \mathrm{RDN}+25 \% \mathrm{~N}$ through neem cake. The study suggested that application of $75 \% \mathrm{RDN}+25 \% \mathrm{~N}$ through neem cake followed by recommended dose of inorganic fertilizers was found more beneficial and significantly improved growth and yield of radish.

\section{Introduction}

Radish (Raphanus sativus L.) is a popular root vegetable in both tropical and temperate regions belongs to Brassicaceae family. Radish is grown for its young tender tuberous root which is consumed either cooked or raw. It is a good source of vitamin-c and minerals like calcium, potassium and phosphorus. It has refreshing and diuretic properties. It is also used for neurological headache, sleeplessness and chronic diarrhea. The roots are also useful in urinary complaints and piles. The leaves of radish are good source for extraction of protein on a commercial scale and radish seeds are potential source of nondrying fatty oil suitable for soap making illuminating and edible purposes. Availability of nitrogen is 
important for growing plants as it is a major indispensable constituent of protein and nucleic acid. The primary goal of integrated nutrient management is to combine old and new methods of nutrient management into ecologically sound and economically viable farming systems that utilize available organic and inorganic sources of nutrients in a judicious and efficient way. Radish being a short-duration and quick growing crop, the root growth should be rapid and uninterrupted.

Hence, for the production of good quality radish optimum fertilization through organic, inorganic and biofertilizers are essential (Dhanajaya, 2007). Further, higher cost of nitrogenous fertilizers and its effect on soil health and water, it is becoming imperative to go for alternative and cheaper source like organic manures (Kumar et al., 2014). Keeping in view the above facts, a field experiment was planned to study the influence of organic and inorganic sources of nitrogen on growth and yield of radish at vegetable farm, College of Horticulture, Anantharajupeta, Andhra Pradesh.

\section{Materials and Methods}

The field experiment was conducted at Vegetables block, College of Horticulture, Anantharajupeta, Dr. Y.S.R Horticultural University, Andhra Pradesh. The soil of the experimental field was sandy loam with a $\mathrm{pH}$ of 6.8. The experiment consists of 14 treatments in a Randomized Block Design with three replications. Treatments include $\mathrm{T}_{1^{-}}$ RDF (100:80:50 Kg NPK/ha), $\mathrm{T}_{2}-100 \%$ RDN through FYM, $\mathrm{T}_{3}-100 \%$ RDN through Vermicompost, $\mathrm{T}_{4}-100 \%$ RDN through Neem cake, $\mathrm{T}_{5}-75 \% \mathrm{RDN}+25 \% \mathrm{~N}$ through FYM, $\mathrm{T}_{6}-75 \% \quad \mathrm{RDN}+25 \% \mathrm{~N}$ through Vermicompost, $\mathrm{T}_{7}-75 \% \mathrm{RDN}+25 \% \mathrm{~N}$ through Neem cake, $\mathrm{T}_{8}-50 \% \mathrm{RDN}+50 \% \mathrm{~N}$ through FYM, $\mathrm{T}_{9}-50 \% \mathrm{RDN}+50 \% \mathrm{~N}$ through Vermicompost, $\mathrm{T}_{10}-50 \% \mathrm{RDN}+50 \% \mathrm{~N}$ through Neem cake, $\mathrm{T}_{11}-25 \% \mathrm{RDN}+75 \% \mathrm{~N}$ through FYM, T12-25\% RDN $+75 \% \mathrm{~N}$ through Vermicompost, $\mathrm{T} 13^{-} 25 \% \mathrm{RDN}+$ $75 \% \mathrm{~N}$ through Neem cake and $\mathrm{T}_{14}$-Absolute Control. Nitrogen was applied in two equal splits at basal and 25 DAS as per the treatments. All the plots except absolute control received uniform doses of $80 \mathrm{~kg} \mathrm{P}_{2} \mathrm{O}_{5}$ and $50 \mathrm{~kg} \mathrm{~K}_{2} \mathrm{O} \mathrm{ha}^{-1}$ through SSP and MOP. FYM, vermicompost and neem cake were incorporated as per the treatments to respective plots prior to sowing on the basis of nitrogen percentage.

The seeds of radish cv. Japanese white were dibbled at a spacing of 30x10 $\mathrm{cm}$ in ridge and furrow system. Thinning was done at 10 days after sowing by retaining one seedling per hill. The organic manures under study were FYM, vermicompost, Neem cake and inorganic manures were Urea, SSP and MOP. Both organic and inorganic manures were applied alone and in combinations. Organic manures were applied during field preparation 15 days before sowing. The Nitrogen contents in FYM, Vermi compost and Neem cake was found to be $0.49 \%, 2.73 \%$, and $1.08 \%$ respectively. The observations were taken on their vegetative growth and yield parameters. The recorded observations were statistically analyzed using analysis of variance following the method of Panse and Sukhatme (1978) and the mean values were compared at $5 \%$ level of significance.

\section{Results and Discussion}

\section{Growth parameters}

\section{Plant height}

Plant height of radish was significantly affected by the application of various inorganic and organic sources of nitrogen and their combinations at all the stages of plant growth in radish. There was an increase in 
plant height up to harvesting in all the treatments. At $30 \mathrm{DAS}$, significantly highest plant height of $32.92 \mathrm{~cm}$ was recorded with $\mathrm{T}_{7}$ $-75 \% \mathrm{RDN}+25 \% \mathrm{~N}$ through neem cake, which was significantly superior to all other treatments. The next best treatment was $\mathrm{T}_{1}$ $(29.82 \mathrm{~cm})$ and $\mathrm{T}_{10}-(29.80 \mathrm{~cm})$ which were statistically on par with each other. At 45 DAS, significantly highest plant height of $41.53 \mathrm{~cm}$ was recorded with $\mathrm{T}_{7}-75 \% \mathrm{RDN}+$ $25 \% \mathrm{~N}$ through neem cake which was significantly superior to all other treatments. The next best treatments were $\mathrm{T}_{10}(38.50 \mathrm{~cm})$, $\mathrm{T}_{1}-(38.47 \mathrm{~cm})$, which were statistically on par with each other.

At harvest, significantly highest plant height of $44.38 \mathrm{~cm}$ was recorded with $\mathrm{T}_{7}-75 \% \mathrm{RDN}$ $+25 \% \mathrm{~N}$ through neem cake followed by $\mathrm{T}_{10^{-}}$ $(42.14 \mathrm{~cm}), \quad \mathrm{T}_{1}-(41.42 \mathrm{~cm})$ which were statistically on par with each other. Minimum plant height at 30DAS, 45DAS and at harvest was recorded in absolute control $\left(\mathrm{T}_{14}\right)$ (19.72 $\mathrm{cm}),(25.18 \mathrm{~cm})$ and $(28.93 \mathrm{~cm})$ respectively (Table 1).

The increase in plant height might be due to the presence of readily available form of nitrogen through both inorganic and organic sources (neem cake), wherein inorganic source could have exerted positive influence on extended nutrient availability to match the physiological needs of the crop since it is applied in splits, which triggered to produce elevated stature of the growth components. In addition to that integration of neem cake might have resulted in beneficial influence of nitrification inhibition and amelioration of soil physico chemical properties. Besides, it may also be due to rapid elongation and multiplication of cell in the presence of adequate quantity of nitrogen (Barman et al., 2018). Similar results were reported by Mahokar et al., (2007), Kumar et al., (2014) in radish, Bhattarai and Maharjan (2013) in carrot and Veena et al., (2017) in chilli.

\section{Leaf length}

There was an increase in leaf length in all the treatments with the advancement of growth stages.At 30 DAS, 45 DAS and at harvest maximum leaf length $(23.80 \mathrm{~cm}),(33.28 \mathrm{~cm})$ and $(36.97 \mathrm{~cm})$ was recorded in $\mathrm{T}_{7}-75 \% \mathrm{RDN}$ $+25 \% \mathrm{~N}$ through neem cake followed by $\mathrm{T}_{1^{-}}$ $(23.44 \mathrm{~cm}),(32.23 \mathrm{~cm})$ and $(36.62 \mathrm{~cm})$ which were on par with each other.

However $\mathrm{T}_{14}$-absolute control has recorded the lowest leaf length at 30 DAS, 45 DAS and at harvest $(14.51 \mathrm{~cm}),(21.78 \mathrm{~cm})$ and $(26.48$ $\mathrm{cm})$ respectively (Table 1$)$

Probable reasons for enhanced number of leaves might be due to promotive effects of macro and micro nutrients from both inorganic and organic sources of nitrogen (neem cake) on vegetative growth which ultimately lead to more photosynthetic activity. Similar findings have been reported by Mahokar et al., (2007), Kumar et al., (2014) and Khalid et al., (2015) in radish. Further, additional amount of phosphorous and other micronutrients such as zinc, copper and iron from neem cake might have involved in stimulation of root system through efficient translocation of certain growth stimulating compounds leading to better absorption of nitrogen and other nutrients and their utilization might have improved the number and length of leaves (Jat et al., 2017). Similar findings have been reported by Kumar et al., (2014) in radish and Rao et al., (2010) in onion.

\section{Leaf area}

There was an increase in leaf area in all the treatments with the advancement of growth stages. At 30, 45 DAS and at harvest leaf area per plant was maximum with $\mathrm{T}_{7}-75 \% \mathrm{RDN}+$ $25 \% \mathrm{~N}$ through neem cake $\left(922.04 \mathrm{~cm}^{2}\right)$, $\left(2022.05 \mathrm{~cm}^{2}\right)$ and $\left(2463.15 \mathrm{~cm}^{2}\right)$ which was statistically on par with $\mathrm{T}_{1}\left(901.18 \mathrm{~cm}^{2}\right)$, 
$\left(2015.16 \mathrm{~cm}^{2}\right)$ and $\left(2386.17 \mathrm{~cm}^{2}\right)$. At 30 DAS, 45DAS and at harvest minimum leaf area per plant was observed in $\mathrm{T}_{14}$ - absolute control $\left(400.59 \mathrm{~cm}^{2}\right),\left(987.67 \mathrm{~cm}^{2}\right)$ and $\left(1306.67 \mathrm{~cm}^{2}\right)$ respectively (Table 1$)$.

Leaf area represents photosynthetic efficiency in plants. The positive influence of $75 \% \mathrm{RDN}$ $+25 \% \mathrm{~N}$ through neem cake on number of leaves and leaf length might have resulted in highest leaf area over other treatment combinations. Leaf area was increased by macro and micro nutrients, possibly because of available nitrogen from inorganic and neem cake manure which helps in greater assimilation of food materials by the plant which resulted in greater meristematic activities of cells. These results were well supported by Kumar et al., (2014) in radish and Rao et al., (2010) in onion.

\section{Fresh weight and dry weight of shoot}

Fresh weight and dry weight of shoot increased progressively as the age of the crop advances (Table 2). The highest fresh weight of shoot at 30 DAS and 45 DAS was obtained with $\mathrm{T}_{7}-75 \% \mathrm{RDN}+25 \% \mathrm{~N}$ through neem cake (28.44 $\left.\mathrm{g} \mathrm{plant}^{-1}\right)$ and (166.87 $\left.\mathrm{g} \mathrm{plant}^{-1}\right)$ which was in parity with $\mathrm{T}_{1}\left(28.03 \mathrm{~g} \mathrm{plant}^{-1}\right.$ and $163.41 \mathrm{~g} \mathrm{plant}^{-1}$ ) and both of them were significantly superior over other treatments. At harvest highest fresh weight of shoot was registered with $\mathrm{T}_{7}-75 \% \mathrm{RDN}+25 \% \mathrm{~N}$ through neem cake (234.57 $\left.\mathrm{g}_{\text {plant }}{ }^{-1}\right)$, which was however comparable with $\mathrm{T}_{10}(227.59 \mathrm{~g}$ plant $\left.^{-1}\right)$.

While the lowest fresh weight of shoot at 30 DAS, 45 DAS and at harvest was recorded in $\mathrm{T}_{14}$-absolute control (9.25 $\mathrm{g}$ plant $^{-1}, 90.43 \mathrm{~g}$ plant $^{-1}$ and $136.92 \mathrm{~g} \mathrm{plant}^{-1}$ respectively). At 30 DAS, the highest dry weight of shoot was noticed with $\mathrm{T}_{7}-75 \% \mathrm{RDN}+25 \% \mathrm{~N}$ through neem cake (1.88 $\left.\mathrm{g} \mathrm{plant}^{-1}\right)$ followed by $\mathrm{T}_{1}$ $\left(1.74 \mathrm{~g} \mathrm{plant}^{-1}\right)$ which were statistically similar to each other. The highest shoot dry weight at $45 \mathrm{DAS}$ and at harvest $\left(11.16 \mathrm{~g} \mathrm{plant}^{-1}\right.$ and $17.45 \mathrm{~g}$ plant $^{-1}$ ) was registered with $\mathrm{T}_{7}-75 \%$ $\mathrm{RDN}+25 \% \mathrm{~N}$ through neem cake followed by $\mathrm{T}_{10}\left(10.78 \mathrm{~g}\right.$ plan $^{-1}$ and $\left.17.31 \mathrm{~g} \mathrm{plant}^{-1}\right)$ which were on par with each other. While minimum dry weight of shoot per plant at 30DAS, 45DAS and at harvest was registered with $\mathrm{T}_{14}$-absolute control $\left(0.65 \mathrm{~g}\right.$ plant $^{-1},(6.12$ $\mathrm{g} \mathrm{plan}^{-1}$ and $9.18 \mathrm{~g}$ plan $^{-1}$ respectively).

The beneficial effect of additional nutrients over and above recommended dose of NPK in this combination exerted significant influence of on plant height, leaf number, leaf length and leaf area which ultimately resulting in maximum fresh weight and dry weight of shoot. Further, it was also stated that available nitrogen levels in the above treatment is being synthesized into amino acids leading to luxurious crop growth. Similar results was also observed in Singh et al., (2007) in carrot, Uddain et al., (2010), Kumar et al., (2014) in radish and Umesha et al., (2011) in makoi (Solanum nigrum).

\section{Yield and yield attributes}

\section{Root length and root diameter}

Root length of radish was recorded at harvesting stage (Table 3). Maximum length of root $(31.17 \mathrm{~cm})$ was observed in treatment $\mathrm{T}_{7}$ with $75 \% \mathrm{RDN}+25 \% \mathrm{~N}$ through neem cake which was statistically on par with $T_{1}$ $(29.05 \mathrm{~cm})$, but significantly superior than the rest of the treatments. While the minimum root length $(20.33 \mathrm{~cm})$ was observed in $\mathrm{T}_{14}$ absolute control. At harvest the highest root diameter of the radish was observed in $\mathrm{T}_{7}-$ $75 \% \mathrm{RDN}+25 \% \mathrm{~N}$ through neem cake $(3.84$ $\mathrm{cm})$ followed by $\mathrm{T}_{1}(3.76 \mathrm{~cm})$ which were at par with each other but significantly superior to all other treatments. Absolute control has recorded the lowest root diameter $(2.38 \mathrm{~cm})$. 
Table.1 Influence of organic and inorganic sources of nitrogen on plant height, leaf length, leaf area of radish at different stages of crop growth

\begin{tabular}{|c|}
\hline Growth parameters \\
\hline Treatments \\
\hline $\mathrm{T}_{1}$-RDF (100:80:50 NPK Kg/ha) \\
\hline $\mathrm{T}_{2}-100 \%$ FYM \\
\hline $\mathrm{T}_{3}-\mathbf{1 0 0 \%} \mathrm{VC}$ \\
\hline $\mathrm{T}_{4}-100 \%-\mathrm{NC}$ \\
\hline $\mathrm{T}_{5}-\mathrm{RDN}+\mathrm{FYM}(\mathbf{7 5} \%+25 \%)$ \\
\hline $\mathrm{T}_{6}-\mathrm{RDN}+\mathrm{VC}(\mathbf{7 5 \%}+25 \%)$ \\
\hline $\mathrm{T}_{7}-\mathrm{RDN}+\mathrm{NC}(\mathbf{7 5 \%}+25 \%)$ \\
\hline $\mathrm{T}_{8^{-}}$RDN+ FYM $(50 \%+50 \%)$ \\
\hline $\mathrm{T}_{9}-\mathrm{RDN}+\mathrm{VC}(\mathbf{5 0} \%+\mathbf{5 0} \%)$ \\
\hline $\mathrm{T}_{10}-\mathrm{RDN}+\mathrm{NC}(50 \%+50 \%)$ \\
\hline $\mathrm{T}_{11}-\mathrm{RDN}+\mathrm{FYM}(25 \%+75 \%)$ \\
\hline $\mathrm{T}_{12^{-}} \mathrm{RDN}+\mathrm{VC}(50 \%+50 \%)$ \\
\hline $\mathrm{T}_{13}-\mathrm{RDN}+\mathrm{NC}(25 \%+75 \%)$ \\
\hline $\mathrm{T}_{14}$-Absolute control \\
\hline S. Em. \pm \\
\hline C.D. at $5 \%$ \\
\hline
\end{tabular}

\begin{tabular}{|c|c|c|c|c|c|c|c|c|}
\hline \multicolumn{3}{|c|}{ Plant height (cm) } & \multicolumn{3}{|c|}{ Leaf length $(\mathrm{cm})$} & \multicolumn{3}{|c|}{ Leaf area $\left(\mathrm{cm}^{2}\right)$} \\
\hline $\begin{array}{c}30 \\
\text { DAS }\end{array}$ & $\begin{array}{c}45 \\
\text { DAS }\end{array}$ & $\begin{array}{c}\text { At } \\
\text { harvest }\end{array}$ & $\begin{array}{c}30 \\
\text { DAS }\end{array}$ & $\begin{array}{c}45 \\
\text { DAS }\end{array}$ & $\begin{array}{c}\text { At } \\
\text { harvest }\end{array}$ & $\begin{array}{c}30 \\
\text { DAS }\end{array}$ & $\begin{array}{c}45 \\
\text { DAS }\end{array}$ & $\begin{array}{c}\text { At } \\
\text { harvest }\end{array}$ \\
\hline 29.82 & 17 & & .44 & .23 & 66 & 8 & & 206 \\
\hline 23.36 & & & 3.14 & 9.67 & & & & \\
\hline 24.50 & 32.41 & & .04 & 16 & 3657 & 15 & 2 & 39 \\
\hline 26.67 & 35.16 & (נ) & 19.26 & 29.41 & 32 . & 597.31 & 71 & 973.64 \\
\hline 28.69 & 8.24 & & .43 & 42 & & & & \\
\hline 29.60 & 38.00 & 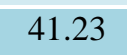 & 21.89 & 26.66 & 31.07 & 845.18 & 1960.44 & 274.38 \\
\hline 32.92 & .53 & 38 & 3.80 & 33.28 & 36.97 & 22.04 & 022.05 & 463.15 \\
\hline 27.86 & 36.27 & 40.17 & 20.14 & 30.01 & 33.13 & 660.53 & 1797.34 & 2014.36 \\
\hline 27.65 & 35.72 & 54 & 19.59 & 29.87 & 2.77 & 3.83 & 676.14 & 2044.48 \\
\hline 29.80 & 38.50 & & 22.36 & 32.22 & 35.97 & 56.46 & 1967.87 & 2296.51 \\
\hline 29.18 & 37.89 & 21 & 21.81 & 31.07 & 34.99 & 30.83 & 57 & 893.25 \\
\hline 28.01 & 35.06 & 39.14 & 20.93 & 29.41 & 31.47 & 672.90 & 1679.35 & 1972.52 \\
\hline 29.01 & 36.17 & 39.18 & 21.80 & 30.50 & 33.99 & 811.75 & 1856.37 & 2114.35 \\
\hline 19.72 & 25.18 & 28.93 & 14.51 & 21.78 & 26.48 & 400.59 & 987.67 & 1306.67 \\
\hline 0.96 & & & 1.00 & 0.97 & 1.03 & 42.02 & 91.52 & 93.67 \\
\hline 2.80 & 2.53 & 2.78 & 2.91 & 2.83 & 2.99 & 122.14 & 266.01 & 272.24 \\
\hline
\end{tabular}

Table.2 Influence of organic and inorganic sources of nitrogen on fresh and dry weight of radish at different stages of crop growth

\begin{tabular}{|c|}
\hline Growth parameters \\
\hline Treatments \\
\hline $\mathrm{T}_{1}$-RDF (100:80:50 NPK Kg/ha) \\
\hline $\mathrm{T}_{2}-100 \%$ FYM \\
\hline $\mathrm{T}_{3}-100 \% \mathrm{VC}$ \\
\hline $\mathrm{T}_{4}-\mathbf{1 0 0 \%}-\mathrm{NC}$ \\
\hline $\mathrm{T}_{5}-\mathrm{RDN}+\mathrm{FYM}(\mathbf{7 5} \%+25 \%)$ \\
\hline $\mathrm{T}_{6}-\mathrm{RDN}+\mathrm{VC}(\mathbf{7 5 \%} \%+25 \%)$ \\
\hline $\mathrm{T}_{7}-\mathrm{RDN}+\mathrm{NC}(\mathbf{7 5} \%+25 \%)$ \\
\hline $\mathrm{T}_{8^{-}}$RDN+ FYM $(50 \%+50 \%)$ \\
\hline $\mathrm{T}_{9}-\mathrm{RDN}+\mathrm{VC}(50 \%+50 \%)$ \\
\hline $\mathrm{T}_{10^{-}} \mathrm{RDN}+\mathrm{NC}(50 \%+50 \%)$ \\
\hline $\mathrm{T}_{11}-\mathrm{RDN}+\mathrm{FYM}(25 \%+75 \%)$ \\
\hline $\mathrm{T}_{12^{-}} \mathbf{R D N}+\mathrm{VC}(\mathbf{5 0} \%+50 \%)$ \\
\hline $\mathrm{T}_{13^{-}} \mathrm{RDN}+\mathrm{NC}(25 \%+75 \%)$ \\
\hline $\mathrm{T}_{14}$-Absolute control \\
\hline S. Em. \pm \\
\hline C.D. at 5\% \\
\hline
\end{tabular}

\begin{tabular}{|c|c|c|c|c|c|}
\hline \multicolumn{3}{|c|}{ Fresh weight of shoot $(\mathrm{g})$} & \multicolumn{3}{|c|}{ Dry weight of shoot (g) } \\
\hline DAS & $\begin{array}{c}\mathbf{4 5} \\
\text { DAS }\end{array}$ & At harvest & 30 DAS & 45 DAS & $\begin{array}{c}\text { At } \\
\text { harvest }\end{array}$ \\
\hline 28.03 & 163.41 & 226.71 & 1.74 & 10.25 & 17.08 \\
\hline 15.28 & 118.38 & 173.12 & 0.92 & 8.13 & 13.71 \\
\hline 13.71 & 109.51 & 170.57 & 0.71 & 8.41 & 13.60 \\
\hline 16.89 & 107.22 & 164.67 & 1.02 & 7.35 & 13.40 \\
\hline 19.09 & 121.56 & 185.71 & 1.16 & 8.62 & 12.26 \\
\hline 19.27 & 151.89 & 209.85 & 1.18 & 10.13 & 15.31 \\
\hline 28.44 & 166.87 & 234.57 & 1.88 & 11.16 & 17.45 \\
\hline 17.68 & 109.03 & 171.23 & 1.07 & 8.17 & 13.83 \\
\hline 24.78 & 131.30 & 166.37 & 1.53 & 9.43 & 13.73 \\
\hline 25.09 & 156.99 & 227.59 & 1.55 & 10.78 & 17.31 \\
\hline 21.11 & 141.42 & 194.44 & 1.30 & 8.74 & 13.39 \\
\hline 17.19 & 111.81 & 179.02 & 1.04 & 7.65 & 14.66 \\
\hline 17.78 & 115.98 & 188.40 & 1.08 & 8.24 & 15.79 \\
\hline 9.25 & 90.43 & 136.92 & 0.65 & 6.12 & 9.18 \\
\hline 0.68 & 5.16 & 10.27 & 0.08 & 0.35 & 0.75 \\
\hline 1.99 & 15.00 & 29.86 & 0.23 & 1.01 & 2.18 \\
\hline
\end{tabular}


Table.3 Influence of organic and inorganic sources of nitrogen on root length, root diameter, fresh and dry weight of root, total biomass per plant, root shoot ratio and yield of radish

\begin{tabular}{|c|c|c|c|c|c|c|c|}
\hline Yield parameters & \multirow{2}{*}{$\begin{array}{l}\text { Root } \\
\text { length } \\
(\mathrm{cm})\end{array}$} & \multirow{2}{*}{$\begin{array}{c}\text { Root } \\
\text { diameter } \\
(\mathbf{c m})\end{array}$} & \multirow{2}{*}{$\begin{array}{l}\text { Fresh } \\
\text { weight } \\
\text { of root } \\
\text { (g) }\end{array}$} & \multirow{2}{*}{$\begin{array}{c}\text { Dry weight } \\
\text { of root } \\
\text { (g) }\end{array}$} & \multirow{2}{*}{$\begin{array}{l}\text { Total } \\
\text { biomass } \\
\text { plant }^{\mathbf{1}}(\mathrm{g})\end{array}$} & \multirow{2}{*}{$\begin{array}{l}\text { Root } \\
\text { shoot } \\
\text { ratio }\end{array}$} & \multirow{2}{*}{$\begin{array}{l}\text { Root } \\
\text { yield } \\
\text { (t/ha) }\end{array}$} \\
\hline Treatments & & & & & & & \\
\hline $\mathrm{T}_{1}$-RDF (100:80:50 NPK Kg/ha) & 29.05 & 3.76 & 277.17 & 15.28 & 503.88 & 1.22 & 34.17 \\
\hline $\mathrm{T}_{2}-100 \%$ FYM & 24.70 & 2.75 & 150.79 & 8.31 & 323.91 & 0.87 & 24.23 \\
\hline $\mathrm{T}_{3}-100 \% \mathrm{VC}$ & 25.02 & 2.85 & 136.89 & 7.54 & 307.46 & 0.80 & 22.14 \\
\hline $\mathrm{T}_{4}-100 \%-\mathrm{NC}$ & 26.17 & 3.02 & 148.23 & 8.16 & 312.90 & 0.91 & 23.21 \\
\hline $\mathrm{T}_{5}-\mathrm{RDN}+\mathrm{FYM}(\mathbf{7 5 \%} \%+25 \%)$ & 28.40 & 3.40 & 187.57 & 10.34 & 373.28 & 1.04 & 25.76 \\
\hline $\mathrm{T}_{6}-\mathrm{RDN}+\mathrm{VC}(75 \%+25 \%)$ & 28.45 & 3.42 & 233.50 & 12.87 & 443.35 & 1.11 & 27.57 \\
\hline $\mathrm{T}_{7}-\mathrm{RDN}+\mathrm{NC}(\mathbf{7 5} \%+25 \%)$ & 31.17 & 3.84 & 306.54 & 16.89 & 541.11 & 1.32 & 38.06 \\
\hline $\mathrm{T}_{8^{-}}$RDN+ FYM $(50 \%+50 \%)$ & 27.61 & 3.27 & 176.56 & 9.73 & 347.79 & 1.03 & 25.28 \\
\hline $\mathrm{T}_{9}-\mathrm{RDN}+\mathrm{VC}(50 \%+50 \%)$ & 28.00 & 3.35 & 151.52 & 8.35 & 317.89 & 0.91 & 25.12 \\
\hline $\mathrm{T}_{10^{-}} \mathrm{RDN}+\mathrm{NC}(50 \%+50 \%)$ & 29.00 & 3.68 & 248.10 & 13.67 & 475.69 & 1.09 & 30.87 \\
\hline $\mathrm{T}_{11}-\mathrm{RDN}+\mathrm{FYM}(25 \%+75 \%)$ & 27.50 & 3.08 & 197.28 & 10.87 & 391.73 & 1.01 & 25.98 \\
\hline $\mathrm{T}_{12^{2}} \mathrm{RDN}+\mathrm{VC}(50 \%+50 \%)$ & 27.06 & 3.19 & 186.68 & 10.33 & 365.70 & 1.05 & 25.36 \\
\hline $\mathrm{T}_{13}-\mathrm{RDN}+\mathrm{NC}(25 \%+75 \%)$ & 28.17 & 3.37 & 187.10 & 10.31 & 375.51 & 0.99 & 25.88 \\
\hline $\mathrm{T}_{14}$-Absolute control & 20.33 & 2.38 & 101.24 & 5.68 & 238.16 & 0.74 & 17.29 \\
\hline S. Em. \pm & 1.01 & 0.11 & 9.58 & 0.74 & 16.39 & 0.06 & 0.88 \\
\hline C.D. at $5 \%$ & 2.95 & 0.33 & 27.85 & 2.14 & 47.64 & 0.17 & 2.56 \\
\hline
\end{tabular}

The increase in root length of radish with 75 $\% \mathrm{RDN}+25 \% \mathrm{~N}$ through neem cake might be due to higher content of $\mathrm{P}(1.01 \%)$ in neem cake. Phosphorus stimulates root growth, greater absorption and translocation of nutrients. Phosphorus at early stages of growth may be involved in stimulation of root system. It is also a part of various enzymes, co enzymes and energy rich ATP resulting in increased root growth (Mangal, 1985). Phosphorus also brings about improvement in the physico- chemical characteristics of the soil (Schmidt, 1954). Organic manures play a direct role in plant growth as a source of all necessary macro and micro nutrients in available form during mineralization, improving physical and physiological properties of soil. Similar findings have been reported by Kumar et al., (2014) in radish.

\section{Fresh weight and dry weight of root}

Significantly the highest fresh weight of root was noticed with $\mathrm{T}_{7}$ with $75 \% \mathrm{RDN}+25 \% \mathrm{~N}$ through neem cake (306.54 gm) followed by $\mathrm{T}_{1}(277.17 \mathrm{gm})$ and both of them were significantly superior over the rest of the treatments. The lowest fresh weight of root was obtained with $\mathrm{T}_{14}$-absolute control (101.24 gm). The highest dry weight of root was obtained with $\mathrm{T}_{7}-75 \% \mathrm{RDN}+25 \% \mathrm{~N}$ through neem cake $(16.89 \mathrm{gm})$ followed by $\mathrm{T}_{1}$ $(15.28 \mathrm{gm})$ which were statistically on par with each other, but significantly superior over all other treatments. Whereas, lowest fresh weight of root (5.68 g) was observed in $\mathrm{T}_{14}$-absolute control (Table 3).

Fresh and dry weight of root was increased with combination of organic and inorganic sources of nitrogen which might be due to increase in leaf number, leaf length and leaf area which ultimately results in maximum photosynthetic efficiency and better assimilation. Rapid synthesis and translocation of photosynthates from source (leaves) to sink (roots) might have contributed to increased fresh weight and dry weight of 
roots. Decrease in bulk density and increase in porosity and water holding capacity of the soil due to neem cake might have also contributed to the increase in yield attributes of the radish. Further it may be due to solubulization of plant nutrients by addition of inorganic fertilizers and neem cake leading to increased uptake of NPK by the plant. These findings were in agreement with those reported by Kumar et al., (2009), Uddain et al., (2010) and Kumar et al., (2014) in radish.

Urea and S.S.P as a source of nitrogen and phosphorus respectively, were found most effective in increasing the root weight of radish (Lakra et al., 2017). Vijayakumari et al., (2012) reported that treatment combinations consisting of NPK showed significant increase in fresh weight of root in radish. Otani (1974) reported that fresh weight of root increased with nitrogen. Similar reports of significant effect of nitrogen on fresh weight of root were reported by Ali et al., (2006) in carrot.

\section{Total biomass per plant and root shoot ratio}

The highest biomass per plant (541.11 g) was observed in $\mathrm{T}_{7}$ treatment with $75 \% \mathrm{RDN}+$ $25 \% \mathrm{~N}$ through neem cake followed by $\mathrm{T}_{1-}$ RDF (503.88 g). However both these treatments were on par with each other and significant over all other treatments. While the lowest total biomass per plant was observed in $\mathrm{T}_{14}$-absolute control (238.16 $\mathrm{gm})$. The highest root shoot ratio was observed in $\mathrm{T}_{7}(1.32 \mathrm{gm})$ with $75 \% \mathrm{RDN}+$ $25 \% \mathrm{~N}$ through neem cake followed by $\mathrm{T}_{1}$ (1.22) with RDF. Both the treatments were on par but significant than all other treatments. While minimum root shoot ratio (0.74) was observed in $\mathrm{T}_{14}$ - absolute control (Table 3 ).

The maximum total biomass weight plant ${ }^{1}$ was recorded with $(75 \% \mathrm{RDN}+25 \% \mathrm{~N}$ through neem cake. The total biomass is directly influenced by leaf number, leaf length, leaf area, fresh weight of leaves, root length, root diameter and root weight of plant. The positive influence of $75 \% \mathrm{RDN}+25 \%$ $\mathrm{N}$ through neem cake on growth parameters has subsequently reflected in improving the yield attributes. Decrease in bulk density and increase in porosity and water holding capacity of the soil due to neem cake might have also contributed to the increase in yield attributes of the radish. Solubulization of plant nutrients by addition of inorganic fertilizers and neem cake resulting in increased uptake of NPK and total biomass of the plant. These findings were in agreement with those reported by Sunandarani and Mallareddy (2007), Kumar et al., (2009), Kanaujia et al., (2010), Uddain et al., (2010) and Kumar et al., (2014) in radish. The highest root to shoot ratio was recorded with $75 \% \mathrm{RDN}+25 \% \mathrm{~N}$ through neem cake which might be due to higher phosphorus availability from neem cake $(1.87 \%)$ which happened due to application of manures on equal nitrogen basis and readily available nutrients from inorganic source of RDN.

\section{Root yield (t/ha)}

The highest root yield tonnes $\mathrm{ha}^{-1}(38.06 \mathrm{t}$ ha ${ }^{1}$ ) was recorded in $\mathrm{T}_{7}$ with $75 \% \mathrm{RDN}+25 \%$ $\mathrm{N}$ through neem cake which was significantly superior to all other treatments (Table 3). The next best treatments $\left(T_{1}\right)$ followed by $\left(T_{10}\right)$ which were significantly superior to all other treatments. However lowest root yield $\mathrm{t} \mathrm{ha}^{-1}$ (17.29 $\mathrm{t} \mathrm{ha}^{-1}$ ) was recorded with absolute control.

The increase in root yield might be due to cumulative effect of all the growth parameters viz., plant height, leaf area, fresh weight, dry weight of shoot and yield components viz., root length, root diameter, fresh and dry weight of root with readily available nitrogen 
in $75 \% \mathrm{RDN}+25 \% \mathrm{~N}$ through neem cake treatment.

The slow release of nutrients from organic manures and readily available nitrogen from inorganic fertilizers in radish throughout the growing period might have resulted in higher root yield of radish. Similar results of increased yield with neem cake were reported in radish by Sharma et al., (1986) and Amarendra et al., (1997) in tomato. Increased yield due to better availability of nutrients and the balanced $\mathrm{C}$ : $\mathrm{N}$ ratio might have increased synthesis of carbohydrates which ultimately promoted greater yield (Jose et al., 1998). It can also be due to better accumulation of carbohydrates in the plants. The translocation of photosynthates from source (leaves) to sink (root) might have contributed to increased root length and root diameter resulting in root yield.

On the basis of the results obtained in the present investigation, it may be concluded that application of $75 \% \mathrm{RDN}+25 \% \mathrm{~N}$ through neem cake $\left(\mathrm{T}_{7}\right)$ followed by $100 \%$ RDF $\left(\mathrm{T}_{1}\right)$ can be considered as the best treatment for obtaining better growth and yield in radish.

\section{References}

Ali, M.K., Barkotulla, M.A.B., Alam, M.N and Tawab, K. A. 2006. Effect of nitrogen levels on yield and yield contributing characters of three varieties of carrot. Pakistan Journal of Biological Sciences. 9(3): 553-57.

Amarendra, K, Prasad, K.K, Jain, B.P. and Kumar, A. 1997. Effect of organic amendments and chemicals on growth and yield of tomato (Lycopersicon esculentum Mill.) Journal of Research Bisra Agricultural University. 9(1): 4952.
Bhattarai, B.P. and Maharjan, A. 2013. Effect of organic nutrient management on the growth and yield of carrot (Daucus carota L.) and soil fertility status. Nepalese Journal of Agricultural Sciences. 11: 16-25.

Dhananjaya, J. 2007. Organic Studies in Radish (Raphanus sativus L.) Varieties. Department of Horticulture College of Agriculture, Dharwad University of Agriculture Science, Dharwad - 580 005. PP.12-13.

Jat, P.K., Singh, S.P., Devi, S. and Rolaniya, M.K. 2017. Influenced of organic, inorganic manure and plant density on growth and yield of radish (Raphanus sativus L.). Chemical Science Review and Letters. 6(21): 401-05.

Kanaujia, S.P., Singh, V.B. and Singh, A.K. 2010. INM for quality production of radish (Raphanus sativus L.) in acid alfisol. Journal of Soils and Crops. 20(1): 1-9.

Kumar, M, Kumar, S, Rattan, P, Sharma, J.P. and Rai, G.K. 2009. Response of radish to the use of integrated nutrient management practices. Vegetable Science. 36(3): 406- 07.

Kumar, S, Maji, S, Kumar, S. and Singh, H.D. 2014. Efficacy of organic manures on growth and yield of radish (Raphanus sativus L.) cv. Japanese White. International Journal of Plant Science. 9(1): 57-60.

Lakra, A, Singh, D, Prasad, V.M., Deepanshu and Shabi, M. 2017. Effect of nitrogen and phosphorus on growth and yield of radish (Raphanus sativus L.) cv. Pusa chetki under shade net condition. The Pharma Innovation Journal. 6(11): 76870.

Mahokar, V.K., Bodkhe, V.A., Ingle, V.G., Jadhao B.J. and Gomase, D.G. 2007. Effect of various organic manures on growth and yield of radish. Asian Journal of Horticulture. 2(1): 155-57. 
Mangal, J.L. 1985. Effect of nitrogen and phosphorus application on growth and yield of onion. Indian Journal of Horticulture. 42(2): 152-54.

Otani, K. 1974. Effect of nitrogen fertilizer on carotenoid content in carrots. Journal of Agricultural Science. 18: 270-73.

Panse, V.G. and Sukhatme, P.V. 1978. Statistical methods for agricultural workers. Indian council of Agricultural research, New Delhi.

Rao, K.R., Mushan, L.C., Mulani, A.C., Khatavkar, R.S., Parlekar, G.Y. and Shah, N.V. 2010. Effect of vermicompost on the growth yield of onion (Allium cepa). Karnataka Journal of Agricultural Sciences. 23(2): 361-63.

Schmidt, L. 1954. Soils Fertility, Harpenden. 18,310 .

Sharma, H.L, Singh, C.M. and Kapur, B.C. 1986. Effect of neem cake blended urea on germination and yield of radish. Indian Journal of Agricultural Sciences. 56(11): 802-804.

Singh, B.N., Singh, A.P., Singh, T. and Singh, N.K. 2007. Integrated nutrient management in carrot (Daucus carota L.). Progressive Agriculture 7(1and 2): 84-86.

Sunandarani, N. and Mallareddy, K. 2007. Effect of different organic manures and inorganic fertilizers on growth, yield and quality of carrot (Daucus carota L.). Karnataka Journal of Agricultural Sciences. 20(3): 686-88.

Uddain, J, Chowdhury, S. and Rahman, M.J. 2010. Efficacy of different organic manures on growth and productivity of radish (Raphanus sativus L.) International journal of Agriculture, Environment and Biotechnology. 3(2): 189-93.

Umesha, K, Soumya, S.P., Smitha, G.R. and Sreeramu, B.S. 2011. Influence of organic manures on growth, yield and quality of makoi (Solanum nigrum L.). Indian Journal of Horticulture. 68(2): 235-39.

Veena, S.K., Giraddi, R.S., Bhemmanna, M. and Kandpal, K. 2017. Effect of neem cake and vermicompost on growth and yield parameter of chilli. Journal of Entomology and Zoology Studies. 5(5): 1042-44.

Vijayakumari, B, Sasikala, V. and Poornima, C.P. 2012. Effect of organic and inorganic manures on biometric and yield parameters of radish (Raphanus sativus L.) cv. Pusaphepki. International Journal of Plant Sciences. 7(1): 130-34.

\section{How to cite this article:}

Naveen Yadav, B., P. Syam Sundar Reddy, Syed Sadarunnisa, G. Srinivasarao, Y. Deepthi Kiran and Lalitha Kadiri. 2018. Influence of Organic and Inorganic Sources of Nitrogen on Growth and Yield of Radish (Raphanus sativus L.). Int.J.Curr.Microbiol.App.Sci. 7(08): 44994507. doi: https://doi.org/10.20546/ijcmas.2018.708.476 